\title{
BIOBLITZ OF THE LAKE ROSSIGNOL WILDERNESS AREA
}

\author{
FRANCES ANDERSON, JAMES BRUNT, ROBERT \\ CAMERON*, BRENNAN CAVERHILL, DIANE CLAPP, \\ HAROLD CLAPP, BETHANY COULTHARD, SARAH \\ HART, LEIF HELMER, SCOTT HUBLEY, DONNA \\ HURLBURT, TARA IMLAY, RYAN JAMESON, PETER \\ KIDD, COLIN LAROQUE, ROBBY MAROTTE, KATIE \\ MARSHALL, SEAN C. MITCHELL, TOM NEILY, KATIE \\ NICKERSON, NATASHA O'NEILL, BEN PHILLIPS, \\ CATHERINE PROSS, GINI PROULX, LISA PROULX, \\ CAROLYN REARDON, JOSIE TODD, JULIE TOWERS
}

\begin{abstract}
The Lake Rossignol Wilderness Area is a 4100 ha protected area in Queens County, Nova Scotia. In July, 2006, the Protected Areas Branch of Nova Scotia Environment invited 34 scientists, students and volunteers to conduct a four day bioblitz of this little studied protected area. Surveys were conducted for reptiles, fish, vascular plants, fungi, lichens and bryophytes. Physical and biological attributes of peatlands and dendrochronological studies were also conducted. A total of 294 species were identified during the survey, 285 of which are new records for the Wilderness Area. Dendrochronological analysis suggests trees at the site have been growing in place for at least the last 350 years.
\end{abstract}

Keywords: Lake Rossignol Wilderness Area, bioblitz

\section{INTRODUCTION}

The term bioblitz was first used during an event held at the Kenilworth Aquatic Gardens in Washington, D.C. in 1996 (Shorthouse 2010). Since then, the bioblitz has become a useful technique for scientists to rapidly assess the biodiversity of protected areas, establish new species records and in some cases identify new species to science. A new species of fungus, Trifoliellum bioblitzii, was found in 2009 during a bioblitz of the Blue Mountain-Birch Cove Lakes Wilderness Area in Nova Scotia. Other events have also revealed significant new

* Author to whom correspondence should be addressed: Nova Scotia Environment, PO Box 442, Halifax, Nova Scotia, B3J 2P8; Email: camerorp@gov.ns.ca 
species. For example Harper et al. (2009) described two species of a newly identified genus as a result of a marine bioblitz in New Zealand (2009). In addition to establishing new species records (for example see Lewington and West 2008, Karns et al. 2006) the bioblitz can lead to the discovery of biodiversity hotspots (Graham et al. 2010). Some bioblitzes are taxa specific such as the annual Biological Survey of Canada insect blitz (Shorthouse 2010), the Tuckerman workshop survey for lichens and bryophytes (Lendemer and Hodkinson 2009) or the more specific exotic herpeto-faunal bioblitz in Barnacle Historic State Park in 2005 (Meshaka et al. 2008).

There are several reasons for conducting bioblitzes in Nova Scotia. Foremost is to increase knowledge about the biota found in little studied protected areas of Nova Scotia. The opportunity for scientists of different disciplines to interact and learn about other specialities has often been cited by participants as an important part of the survey event. The survey can also be a useful learning experience for students and volunteers who participate.

In 2004 the Protected Areas Branch of Nova Scotia Environment, in conjunction with the Biology Department of St. Francis Xavier University, conducted the first multi-disciplinary bioblitz in Nova Scotia at Canso Coastal Barrens Wilderness Area. Ten scientists and students conducted an inventory of a variety of species groups over a single day. Since then, the Protected Areas Branch has conducted three more bioblitzes in other protected areas (Scatarie Island, Lake Rossignol, Tangier Grand Lake) ranging from two to four days.

In 2006, the Protected Areas Branch invited 34 scientists, students and volunteers to a bioblitz in the Lake Rossignol Wilderness Area. Participants conducted inventories between 26 and 29 July 2006 in a variety of disciplines. Some sampling was also conducted in 2007 and 2008.

The Lake Rossignol Wilderness Area is a 4100 ha protected area in Queens County, Nova Scotia. The area was designated in 1998 under the provincial Wilderness Areas Protection Act. This Act restricts activities such as development, forestry, mining and destruction or removal of natural materials. The Lake Rossignol Wilderness Area was designated in part to protect representative ecosystems of the LaHave Drumlins and Lake Rossignol Hills Natural Landscapes (Cameron 2004, Lynds and LeDuc 1995). 
Historical human impacts to North Queens County have included forestry and agriculture. Forest was cleared for agriculture with about $4.4 \%$ of North Queens under agriculture in 1870, although this declined to about $1.1 \%$ by 1966 (Telfer 2004). Forestry in the area was historically limited to small patches and individual trees but more recently has included larger clearcuts and conversion of mixed forest to plantations (Telfer 2004). Lake Rossignol was dammed in the 1920 's by forestry companies which considerably enlarged the lake converting previous forest to lake (Davis and Browne 1996). Lake Rossignol Wilderness Area is relatively remote and has seen little recent human activity. However, there has been some recent forest harvesting and road construction around the Wilderness Area (Cameron 2004). There is also some evidence of past forest harvesting and farming in the Wilderness Area (R. Cameron pers. comm.). Atmospheric deposition of non-marine $\mathrm{SO}_{4}$ and $\mathrm{NO}_{3}$ between 1977-1980 has led to the acidification of lakes in southwest Nova Scotia (Underwood et al. 1987). Although $\mathrm{SO}_{4}$ and $\mathrm{NO}_{3}$ have declined in the last several decades, deposition has continued to exceed critical loads for upland forest soils and aquatic ecosystems (Ouimet et al. 2006, Environment Canada 2004). The susceptibility to acid precipitation is largely due to the low buffering capacity of acid bedrock and soils in that part of Nova Scotia (Davis and Browne 1996).

Although the Lake Rossignol Wilderness Area was designated to protect representative ecosystems, there have been no systematic biological surveys of the area with the exception of some vegetation surveys collected in 1992 and 2003 (Cameron 2004). These data collections were confined to forest ecosystems and no study had been conducted in the large area of wetland in the southern portion of the protected area (Davis and Browne 1996).

Lake Rossignol Wilderness Area was considered a likely candidate to provide habitat for a variety of rare species. Two lakes within the Wilderness Area and six lakes that border it provide potential habitat for coastal plain flora, eastern ribbon snake (Thamnophis sauritus) and Blanding's turtle (Emydoidea blandingii). Large wetlands in the Wilderness Area are also potential habitat for coastal plain flora. 


\section{METHODS}

\section{Study Area}

The Lake Rossignol Wilderness Area is between $44^{\circ} 18^{\prime}$ and $44^{\circ} 11^{\prime}$ north latitude and $65^{\circ} 8^{\prime}$ and $64^{\circ} 59^{\prime}$ west longitude in Queens County, Nova Scotia (Figure 1). The Wilderness Area is in the north temperate forest region with high annual precipitation (1200 to $1400 \mathrm{~mm}$ ) and relatively warm summer temperatures (average July temperature of $18^{\circ} \mathrm{C}$ ). Underlying geology is mainly quartzite overlain with stony or silty till, silty till drumlins and organic material. Mature mixed forests dominate much of the protected area but large wetlands are found in the south-eastern portion. There are three lakes within the protected area, Big Rocky, Little Rocky and Moccasin Lakes with an area of 263 ha, 51 ha and 73 ha respectively (Cameron 2004).

Adjacent to Lake Rossignol Wilderness Area is property owned by Bowater Mersey and under conservation easement with the Nature Conservancy of Canada. This area was visited on 27 July 2006 by the survey participants. Data from this area are included in this study.

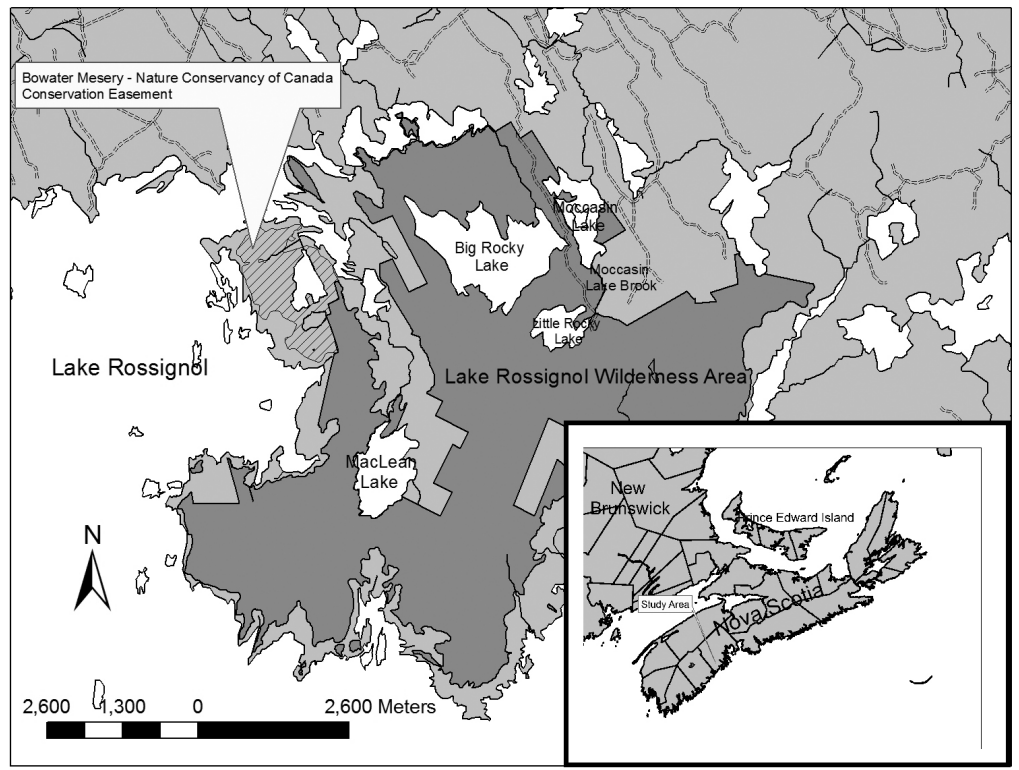

Fig 1 Map of Lake Rossignol Wilderness Area, Nova Scotia showing general location and major features. 


\section{Biological Sampling}

\section{Fish}

Standard minnow traps and fyke nets (length $3 \mathrm{~m}$; mouth $0.40 \mathrm{~m}^{2}$; mesh size $1.5 \mathrm{~cm}$ ) were set between 26 and 28 July in three lakes within the Wilderness Area - Big Rocky Lake, Moccasin Lake, and Apple Tree Lake. Minnow traps were baited with beef liver. Captured fish were identified to species, measured for length and either returned unharmed to the water or sacrificed (two fish) to be archived in the collection at St. Francis Xavier University, Antigonish, Nova Scotia.

\section{Turtles}

A combination of visual surveys and live-trapping was employed. Visual surveys were conducted each day for about 2 hours, while setting, checking, and removing aquatic hoop-net live-traps baited with sardines. On July 26, 2007, 12 live-traps were set and baited along the length of Moccasin Lake Brook, in suitable turtle habitat (stillwaters with dense aquatic vegetation). The traps were checked once a day, for three days, and were removed on July 29, 2007. Setting 12 traps for 3 nights yielded a total of 36 trap-nights, and about 8 hours of visual survey time. All trap-captured turtles were identified and released immediately after capture.

\section{Snakes}

Visual surveys were conducted on July 28 and 29, 2006, along the shore of Lake Rossignol, Moccasin Lake Brook, and in a swamp adjacent to Lake Rossignol. These surveys involved observers walking or canoeing in parallel transects through the wetland with 1-10 m between each observer. Attempts were made to catch eastern ribbon snakes when observed; all snakes were released at the point of capture. A total distance of $6009 \mathrm{~m}$ was covered by walking, $499 \mathrm{~m}$ covered by canoe, and $9.7 \mathrm{hr}$ of observer effort was exerted.

\section{Vascular Plants}

Vascular plants were identified and collected between 26 and 28 July, 2006. Five to seven observers with one recorder visited different areas of the Wilderness Area each day and a separate species list was generated for each day. If a plant species was encountered on more than one day, duplicate specimens were not collected. Digital photos and Global Positioning System (GPS) coordinates were taken at collection sites with rare or unusual species or particularly rich 
sites. Collections were made of each species encountered and were later pressed and deposited at the E.C. Smith Herbarium at Acadia University or the Nova Scotia Museum of Natural History Herbarium. Nomenclature follows Zinck (1998).

\section{Fungi}

The collections of fruiting bodies of fungi were made on 26 July, on the west facing hillside in the north eastern end of the Wilderness Area and on 27 July in the Bowater Mersey - Nature Conservancy of Canada conservation easement.

Photographs were taken of the cap, gills, and stipe of each specimen. Specimens could not be preserved, but spores were kept when spore prints were produced. Measurements of cap diameter and of stipe length and diameter were recorded. Identification to species was done in the field and later with photographs and spore prints.

\section{Lichens}

Two habitat types were selected for intensive survey; a small unnamed brook connecting Carrigan Lake and Big Rocky Lake and a treed swamp south of Little Rocky Lake. These habitat types are commonly targeted by the authors for surveys because of the high diversity of macrolichens expected to be found on both hardwood and coniferous species. Although most of the surveying occurred in these two habitats, observations were not limited to them and opportunistic collections were also made in other locations. Identifications were made in the field. Those species that could not be identified in the field were collected and later identified in a labratory using various keys. Collections were made of thirty-nine specimens which were later deposited in the Nova Scotia Museum of Natural History.

\section{Bryophytes}

Bryophytes were identified or collected between 26 and 29 July, 2006, and 22 April, 2008. Species identified in the field were recorded by substrate on which they occurred. Species that could not be identified in the field were collected and later identified in the laboratory using Ireland (1982). Collected specimens were deposited at the Nova Scotia Museum of Natural History. Searches for bryophytes were conducted such that a variety of habitats and substrates were visited. Habitat types visited included mature mixedwood and hemlock forest, treed fen, brook and lake riparian zones. 


\section{Dendrochronology}

Standard dendrochronology practices were used to sample 24 eastern hemlock (Tsuga canadensis) trees at the Bowater Mersey Nature Conservancy of Canada conservation easement. Two cores were taken at breast height for each tree. Cores were taken at $180^{\circ}$ to one another since the trees were found growing on a slope. This was done to acquire cores that could be used together to derive the average growth of the tree species at the site.

All cores taken were transported back to the Mount Alison Dendrochronology Labratory, air dried, and glued into slotted mounting boards. The cores were then sanded to a 600 grit polish. The ring widths of each sample were measured using a WinDendro computer software system and a high resolution flatbed scanner. All ring widths were measured to $0.001 \mathrm{~mm}$. Ring width patterns for each species were cross dated both visually and statistically using program COFECHA (Holmes et al., 1986). COFECHA correlations were derived using 50 year segments lagged successively by 25 years. Tree patterns that exhibited correlation coefficients greater than 0.3281 were significant to the $99 \%$ level. Each data set was then analyzed with program ARSTAN (Cook 1999) with a single detrending method to derive a master average chronology that illustrated the unified growth signal of all trees.

\section{Intensive focus of a Peatland}

The diversity of four different taxonomic groups was surveyed within the peatland using standardized methods:

Odonate Sampling - Sampling took place as observers moved through the study site in a semi-random fashion. Upon entering a bog, a random direction was chosen from all possible directions that led away from the edge of the bog. This direction represented a linear transect which was walked by the observer until an adult odonate was encountered. Odonates encountered were captured using white $33 \mathrm{~cm}$ diameter aerial insect nets with a 1.5 or $0.6 \mathrm{~m}$ handle. When possible, odonates were identified in the field and released after adding a small mark to their wing using a waterproof pen to prevent double counting. However, when field identification was not possible, specimens were collected and preserved for later identification. After capture, a new random direction was chosen and this process was continued. When observers encountered the bog edge during transects, a new random direction was chosen that led away from the edge of the bog. 
Collected specimens were defatted using a 24-36 hour acetone bath and then air dried for preservation. Odonates were identified using a standard dissecting microscope and a range of taxonomic keys.

Tabanids (horse and deerflies) of the family Tabanidae were sampled by hand netting and with modified Manitoba traps. Manitoba traps are plastic and wooden cones that were baited with a suspended beach ball covered by a garbage bag and Octanol, a tabanid attractant. Female tabanids attracted to the trap tend to fly upwards, funneled by the cone shape of the trap, into the collecting head. A $2 \mathrm{~cm}^{3}$ cube of Vapona (Scotts Canada Ltd.) was placed in the collecting head to act as an insecticide. Males were captured by aerial net as they are not attracted to traps. A trap was placed in an open area of the bog, approximately $10 \mathrm{~m}$ from the tree-line for approximately 3 hours. Typically, sampling occurs for longer trap sessions and for a minimum of three periods during the summer; late May-early June, early-mid July, and early-mid August. The extended trapping time was not done in this study because of the short duration of the survey.

Collected specimens were initially frozen. Individual specimens were prepared and pinned within three weeks and subsequently identified to species with a binomial key. Individuals of the genus Atylotus were not identified due to a small number of specimens to examine, and lack of access to reference material.

Vegetation - Woody vegetation and Sphagnum moss diversity was surveyed using three 2 X 50-m belt transects. Each transect was established in random directions from the peatland edge in different sub-habitats within each bog (e.g. lag swamp, open bog, shrub bog, treed bog, poor fen). All species of woody vegetation under 2-m and Sphagnum mosses that were encountered within the belt transect were recorded and relative abundance scored. Habitat and habit of each recorded Sphagnum species was noted (e.g. hummock, hollow, lawn, submerged, etc.).

Other Species - All observations of orchids, reptiles and amphibians were recorded during other activities. Additional time was spent around pools searching for amphibians. 


\section{RESULTS AND DISCUSSION}

\section{Turtles}

Two snapping turtles (Chelydra serpentine L.) and twelve painted turtles (Chrysemys picta Sch.) were captured in the aquatic live-traps. No turtles were seen during visual surveys.

Two of the four species of freshwater turtle known to exist in Nova Scotia were confirmed to reside in the Lake Rossignol Wilderness Area.Even though no wood or Blanding's turtles were seen or captured, we cannot prove their absence, and more time and effort would be required to be conclusive. The nearest Blanding's turtle population is in Kejimkujik National Park, roughly 9 km northwest of Lake Rossignol Wilderness Area (McMaster and Herman 2000). Wood turtles are better known from northern Nova Scotia and southern Cape Breton Island (Gilhen 1984), although there are some records for Annapolis County in the Atlantic Canada Conservation Data Centre Records.

\section{Snakes}

Although surveys were targeted for the eastern ribbon snake (Thamnophis sauritus), a threatened species in Nova Scotia under the Nova Scotia Endangered Species Act, three of the other four snake species found in this province were also observed (Table 1). The eastern ribbon snake is a cryptic species making sightings infrequent. There were two observations of eastern ribbon snakes - at Moccasin Lake Brook and Little Rocky Lake. Although these two sightings provide us with little information on the density of eastern ribbon snakes in this area, it does provide us with more information on the distribution of the species.

Eastern garter snakes (Thamnophis sirtalis), eastern smooth green snakes (Opheodrys vernalis), and redbelly snakes (Storeria occipitomaculata) are fairly common throughout their range (Gilhen 1984). During the survey 2 eastern garter snakes, 4 smooth green snakes,

Table 1 Species and number of snakes observed during the 2006 Lake Rossignol Wilderness Area Bioblitz.

\begin{tabular}{lc}
\hline Snake Species & Number Observed \\
\hline Eastern Ribbonsnake (Thamnophis sauritus) L. & 2 \\
Eastern Garter Snake (Thamnophis sirtalis) Allen & 2 \\
Smooth Green Snake (Opheodrys vernalis) Harlan & 4 \\
Redbelly Snake (Storeria occipitomaculata) Storer & 1 \\
\hline
\end{tabular}


and 1 redbelly snake were observed. Although our surveys were not targeted for these species, multiple observations suggest that these populations may be healthy.

\section{Fish}

From a total of 327 trap-hours (32\% at each of Apple Tree and Moccasin Lakes, 36\% at Big Rocky Lake) and 80 fyke net-hours (all at Big Rocky Lake), 30 individual fish were captured (Table 2). Within Apple Tree Lake, American eel (Anguilla rostrata Lesueur) and yellow perch (Perca flavescens Mitchell) were captured. In Moccasin Lake, yellow perch and golden shiner (Notemigonus crysoleucas Mitchell) were collected while in Big Rocky Lake, American eel, white perch (Morone americana Gmelin) and brown bullhead (Ameiurus nebulosus Lesueur) were captured in the fyke nets.

Captured fish, except American eel, were selectively measured (not every individual measured) and displayed mean size (+SD; sample size) of $19.0 \mathrm{~cm}(+3.6 ; \mathrm{N}=4)$ for white perch, $7.45 \mathrm{~cm}(+2.4 ; \mathrm{N}=10)$

Table 2 Fish sampling results from three lakes within the Lake Rossignol Wilderness Area between 26 and 28 July, 2006.

\begin{tabular}{|c|c|c|c|c|}
\hline Date & Location(s) $^{1}$ & $\begin{array}{l}\text { Gear type } \\
\text { and effort }\end{array}$ & $\begin{array}{l}\text { Species } \\
\text { captured }\end{array}$ & $\begin{array}{l}\text { Number } \\
\text { captured }\end{array}$ \\
\hline \multirow[t]{6}{*}{ 26-27 July } & $\begin{array}{l}\text { Apple Tree } \\
\text { Lake }\end{array}$ & $\begin{array}{l}\text { Minnow traps }(\mathrm{X} 3) \\
37.5 \text { trap-hours }\end{array}$ & $\begin{array}{l}\text { American } \\
\text { eel }\end{array}$ & 3 \\
\hline & $\begin{array}{l}\text { Big Rocky } \\
\text { Lake }\end{array}$ & $\begin{array}{l}\text { Minnow traps (X3); } \\
57 \text { trap-hours }\end{array}$ & - & 0 \\
\hline & & Fyke net (X1); & White perch & 4 \\
\hline & & 19 hour soak time & Brown bullhead & 1 \\
\hline & Moccasin & Minnow traps (X2); & Yellow perch & 2 \\
\hline & Lake & 39 trap-hours & Golden shiner & 2 \\
\hline 27 July & $\begin{array}{l}\text { Apple Tree } \\
\text { Lake }\end{array}$ & $\begin{array}{l}\text { Minnow traps (X2); } \\
24 \text { trap-hours }\end{array}$ & Yellow perch & 3 \\
\hline \multirow[t]{5}{*}{ 27-28 July } & $\begin{array}{l}\text { Apple Tree } \\
\text { Lake }\end{array}$ & $\begin{array}{l}\text { Minnow traps }(\mathrm{X} 2) \\
42 \text { trap-hours }\end{array}$ & Yellow perch & 1 \\
\hline & $\begin{array}{l}\text { Big Rocky } \\
\text { Lake }\end{array}$ & $\begin{array}{l}\text { Minnow traps (X3); } \\
63 \text { trap-hours }\end{array}$ & - & 0 \\
\hline & & Fyke net (X1); & White perch & 5 \\
\hline & & 21 hour soak time & American eel & 2 \\
\hline & $\begin{array}{l}\text { Moccasin } \\
\text { Lake }\end{array}$ & $\begin{array}{l}\text { Minnow traps }(\mathrm{X} 3) \\
64.5 \text { trap-hours }\end{array}$ & Yellow perch & 7 \\
\hline
\end{tabular}

Geographic coordinates of sampled locations:

Apple Tree Lake

Big Rocky Lake

Moccasin Lake
$4905500 \mathrm{~N} 336500 \mathrm{E}$

$4903400 \mathrm{~N} 337000 \mathrm{E}$

$4903400 \mathrm{~N} 337300 \mathrm{E}$ 
for yellow perch, and $7.75 \mathrm{~cm}(+0.35 ; \mathrm{N}=2)$ for golden shiner. Eels were not measured but length of sampled eels were estimated at 40 $\mathrm{cm}$. The sole brown bullhead was $13.5 \mathrm{~cm}$ (TL).

This survey of the three lakes found only five fish species. Alexander et al. (1986) list 14 fish species found in 58 lakes in Queens County, of which eight species were found in more than 5 of the 58 lakes. In addition to the five species presented here, the other three species listed by those authors were brook charr (Salvelinus fontinalis), white sucker (Catastomus commersoni), and banded killifish (Fundulus diaphanous). Peterson and Martin-Robichaud (1989) attempted to define fish assemblages in lakes of Nova Scotia and the sampled lakes reported here would likely fall within their Assemblage 3 (white sucker, brown bullhead, yellow perch; also containing golden shiner, pumpkinseed sunfish (Lepomis gibbosus), and chain pickerel (Esox niger)). Alexander et al. (1986) also reported significant positive correlations between presence of yellow perch and each of golden shiner and brown bullhead, and between brown bullhead and each of golden shiner and white sucker. Thus, we suspect that the community of these lakes most closely resembles Assemblage 3 of Peterson and Martin-Robichaud with the sampling missing the presence of the white sucker. Alexander et al. (1986) also showed significant negative correlations for presence between brook charr and each of yellow perch and golden shiner, therefore, their absence in the sample results is expected. Big Rocky Lake, with its presence of white perch, may represent a slightly different fish assemblage, or the capture of this species may simply reflect the different sampling methods (fyke net rather than minnow traps).

Future sampling in this area should include multiple methods (fyke net, beach seine, minnow traps, angling) in each lake and the collection of basic water chemistry data ( $\mathrm{pH}$, color, Secchi depth).

\section{Vascular Plants}

One hundred species of vascular plants were found (Table 3). Plant species were typical of the various habitats visited and no at-risk species were encountered within the Protected Area. An unusual hybrid was collected in the bog on July $28^{\text {th }}$ : Platanthera blephariglottis $\mathrm{X}$ dilitata. This hybrid was later confirmed by M. Zinck, botanist at the Nova Scotia Museum of Natural History and the specimen is now held in the museum collection. An incidental collection of downey rattlesnake plantain (Goodyera pubescens), was made just outside 
Table 3 Vascular plants recorded during the Lake Rossignol Wilderness Area bioblitz in 2006. Plant species are recorded by the day they were observed during the bioblitz.

\begin{tabular}{|c|c|c|}
\hline Plant Species Day 1 & Plant Species Day 2 & Plant Species Day 3 \\
\hline Abies balsamea (L.) Mill. & Abies balsamea & Acer pensylvanicum \\
\hline Acer saccharum Marshall & Acer pensylvanica $\mathrm{L}$. & Acer rubrum \\
\hline Aralia nudicaulis L. & Acer rubrum L. & Amelanchier sp. Medicus \\
\hline Betula papyrifera Marshall & Betula papyrifera & $\begin{array}{l}\text { Antennaria neglecta } \\
\text { E. Greene }\end{array}$ \\
\hline Clintonia borealis (Aiton) Raf. & Clintonia borealis & Aralia nudicaulis \\
\hline Coptis trifolia (L.) Salisb. & Corallorhiza maculata & Aronia sp. Medicus \\
\hline $\begin{array}{l}\text { Corallorhiza maculata (Raf.) } \\
\text { Raf }\end{array}$ & Cornus canadensis & $\begin{array}{l}\text { Betula alleghaniensi } \\
\text { Britton }\end{array}$ \\
\hline Cornus canadensis $\mathrm{L}$. & Cypripedium acaule & Betula papyrifera \\
\hline Cypripedium acaule Aiton & $\begin{array}{l}\text { Dryopteris marginalis } \\
\text { (L.) A. Gray }\end{array}$ & $\begin{array}{l}\text { Chamaedaphne calyculata } \\
\text { (L.) Moench }\end{array}$ \\
\hline $\begin{array}{l}\text { Diphasiastrum tristachyum } \\
\text { (Pursh) Holub }\end{array}$ & Epigaea repens L. & $\begin{array}{l}\text { Chimaphila umbellate } \\
\text { (L.) Barton }\end{array}$ \\
\hline Epigaea repens $\mathrm{L}$. & $\begin{array}{l}\text { Eriocaulin aquaticum } \\
\text { (Hill) Druce }\end{array}$ & Coptis trifolia \\
\hline $\begin{array}{l}\text { Gaultheria hispidula } \\
\text { (L.) Muhlenb. ex Bigelow }\end{array}$ & Gaultheria procumbens $\mathrm{L}$. & Cornus canadensis \\
\hline Gaultheria procumbens L. & Gaultheria hispidula & Diervilla lonicera Miller \\
\hline $\begin{array}{l}\text { Gaylussacia baccata (Wang.) } \\
\text { K.Koch }\end{array}$ & Gaylussacia baccata & Epigaea repens \\
\hline Goodyera tesselata Lodd. & & Eriophorum virginicum $\mathrm{L}$. \\
\hline Hamamelis virginiana $\mathrm{L}$. & Goodyera tesselata & Fagus grandifolia Ehrh \\
\hline Ilex glabra (L.) Gray & Hamamelis virginia & Fragaria sp. L. \\
\hline Iris versicolor $\mathrm{L}$. & $\begin{array}{l}\text { Huperzia lucidula } \\
\text { (Michuax) Trevisan }\end{array}$ & Galium mollugo L. \\
\hline Kalmia angustifolia $\mathrm{L}$. & Ilex glabra & Gaultheria hispidula \\
\hline Linnaea borealis $\mathrm{L}$. & Kalmia angustifolia & Gaultheria procumbens \\
\hline Lycopodium annotinum $\mathrm{L}$. & $\begin{array}{l}\text { Ledum groenlandicum } \\
\text { Oeder }\end{array}$ & Gaylussacia baccata \\
\hline Medeola virginiana $\mathrm{L}$. & Linnea borealis & Goodyera tesselata \\
\hline Mitchella repens $\mathrm{L}$. & Lobelia dortmanna $\mathrm{L}$. & $\begin{array}{l}\text { Gymnocarpium dryopteris } \\
\text { (L.) Newman }\end{array}$ \\
\hline Monotropa hypopythis L. & Lycopodium clavatum $\mathrm{L}$. & Hamamelis virginiana \\
\hline Monotropa uniflora $\mathrm{L}$. & Medeola virginiana & Hieracium paniculatum $\mathrm{L}$. \\
\hline Myrica pensylvanica Mirbel. & Mitchella repens & Ilex glabra \\
\hline Osmunda cinnamomea $\mathrm{L}$. & Monotropa hypopithys & Kalmia angustifolia \\
\hline Osmunda regalis $\mathrm{L}$. & Monotropa uniflora & Kalmia polifolia Wangenh. \\
\hline Pinus strobes $\mathrm{L}$. & Nymphea odorata Aiton & Lobelia inflate $\mathrm{L}$. \\
\hline $\begin{array}{l}\text { Platanthera clavellata } \\
\text { (Michx.) Luer }\end{array}$ & Picea rubens Sarg. & Medeola virginiana \\
\hline Polypodium virginianum $\mathrm{L}$. & Pinus resinos Aiton & Mitchella repens \\
\hline Prenanthes sp. L. & Pinus strobes L. & Monotropa hypopythis \\
\hline Pteridium aquilinum (L.) Kuhn & $\begin{array}{l}\text { Polyganun cilinode } \\
\text { Michx. }\end{array}$ & Monotropa uniflora \\
\hline Pyrola eliptica Nutt. & Polypodium virginianum $\mathrm{L}$. & Myrica gale L. \\
\hline Rubus sp. L. & Pontedaria cordata L. & Myrica pensylvanicum \\
\hline Spirea alba Duroi & $\begin{array}{l}\text { Populus tremuloides } \\
\text { Michaux }\end{array}$ & $\begin{array}{l}\text { Nemopanthus mucronata } \\
\text { (L.) trel. }\end{array}$ \\
\hline
\end{tabular}


Table 3 Continued

\begin{tabular}{|c|c|c|}
\hline Plant Species Day 1 & Plant Species Day 2 & Plant Species Day 3 \\
\hline Spirea tomentosa $\mathrm{L}$. & $\begin{array}{l}\text { Pteridium aquilinum (L.) } \\
\text { Kuhn. }\end{array}$ & Nymphea odorata \\
\hline Thelypteris palustris Shott. & & Osmunda cinnamomea \\
\hline Toxicodendron sp. L. & Pyrola elliptica Nutt. & Osmunda regalis \\
\hline Triadenum virginicum (L.) Raf. & Quercus rubra $\mathrm{L}$. & Oxalis stricta $\mathrm{L}$. \\
\hline Trientalis borealis Raf. & & Picea sp. Dietr. \\
\hline Trillium undulatum Willd. & Spirea tomentosa & Pinus strobus \\
\hline $\begin{array}{l}\text { Tsuga Canadensis (L.) } \\
\text { Carriere }\end{array}$ & $\begin{array}{l}\text { Thelypteris noveboracensis } \\
\text { (L.) Nieuwl. }\end{array}$ & Plantago major L. \\
\hline \multirow[t]{22}{*}{ Viburnum cassinoides $\mathrm{L}$. } & Trientalis borealis & $\begin{array}{l}\text { Platanthera hookeri } \\
\text { (Willd.) Lindley }\end{array}$ \\
\hline & $\begin{array}{l}\text { Tsuga Canadensis (L.) } \\
\text { Carrière }\end{array}$ & Pontedera cordata \\
\hline & $\begin{array}{l}\text { Vaccinium macrocarpon } \\
\text { Aiton }\end{array}$ & Populus sp. L. \\
\hline & Vaccinium $s p . \mathrm{L}$ & Prenanthes sp. L. \\
\hline & $\begin{array}{l}\text { Populus grandidentata } \\
\text { Michaux }\end{array}$ & Prunella vulgaris $\mathrm{L}$. \\
\hline & Acer pensylvanicum & Pteridium aquilinum \\
\hline & $\begin{array}{l}\text { Vaccinium angustifolium } \\
\text { Aiton }\end{array}$ & Pyrola eliptica \\
\hline & Achillea millefolium $\mathrm{L}$. & Quercus rubra \\
\hline & Actaea sp. L. & Ranunculus repens $\mathrm{L}$. \\
\hline & Aster accuminatus Michx. & $\begin{array}{l}\text { Rhododendron canadense } \\
\text { (L.) Torr. }\end{array}$ \\
\hline & Aster macrophyllus $\mathrm{L}$. & Rosa sp. L. \\
\hline & $\begin{array}{l}\text { Dennstaedtia punctolobula } \\
\text { (Michaux) T.Moore }\end{array}$ & $\begin{array}{l}\text { Sagittaria latifolia } \\
\text { Willd. }\end{array}$ \\
\hline & $\begin{array}{l}\text { Luzula multiflora (Retz.) } \\
\text { Lej. }\end{array}$ & Sium suave Walter \\
\hline & Melampyrum lineare Desr. & Smilax rotundifolia $\mathrm{L}$. \\
\hline & $\begin{array}{l}\text { Phegopteris connectilis } \\
\text { (Michaux) Watt }\end{array}$ & Spirea tomentosa \\
\hline & $\begin{array}{l}\text { Polystichum acrostichoides } \\
\text { (Michaux) Schott }\end{array}$ & $\begin{array}{l}\text { Toxicodendron radicans } \\
\text { (L.) Kuntz(L.) Kuntse }\end{array}$ \\
\hline & $\begin{array}{l}\text { Streptopus amplexifolius } \\
\text { (L.) DC. }\end{array}$ & Trifolium repens $\mathrm{L}$. \\
\hline & & Vaccinium macrocarpon \\
\hline & & Veronica officinalis L. \\
\hline & & Veronica serpyllifolia $\mathrm{L}$. \\
\hline & & Viburnum cassinoides \\
\hline & & Viola sp. L. \\
\hline
\end{tabular}


the protected area. This orchid is currently designated red (at-risk or may be at-risk) by Nova Scotia Department of Natural Resources. A subsequent visit to the site of this orchid, revealed it to be present in abundance (about 200 plants).

\section{Fungi}

Thirty-four species of fungi were identified (Table 4). Most of the fungi were mycorrhizal and common. One identification is still in question and may not be common. Ten specimens on day one and 15 specimens on day two produced spore prints to help with identification.

\section{Lichens}

Sixty-one macrolichen species were recorded (Table 5). The most significant species observed along the brook site was Anzia colpodes, which is known from most of eastern North America (Brodo 2001) but has been reported from only eight counties in Nova Scotia (Anderson, in prep.) and is not considered widespread in those areas. Cyanolichens of interest observed included Coccocarpia palmicola and Leptogium corticola, both designated Yellow or Sensitive species by Nova Scotia Department of Natural Resources (Anderson 2007).

The treed swamp selected for the survey proved less interesting due to immaturity of tree species and soil dryness, however Fuscopannaria ahlneri listed as Red or At Risk or May Be At Risk was observed on rock. No specimen was collected at the time due to its rarity.

\section{Bryophytes}

Forty-eight species of bryophytes were identified and collected (Table 6). All species were mosses with the exception of four liverworts. All species are relatively common in the province (Ireland 1982) with the exception of Buxbaumia aphylla and Sphagnum torreyanum which are considered S2 (May be vulnerable to extirpation due to rarity or other factors, 6 to 20 occurrences or few remaining individuals) and Mnium stellare and Sphagnum angustifolium which are considered S1 (Extremely rare-may be especially vulnerable to extirpation, typically 5 or fewer occurrences or very few remaining individuals) by the Atlantic Canada Conservation Data Centre. Thirty-six species are terricolous, eight species are epiphytic, two species were found on rotted wood, one was found on rock and one species on rock in water. 
Table 4 Fungi species identified during the Lake Rossignol Wilderness Area bioblitz 2006. Species are organized by area in which they were found and whether a spore print was produced.

\begin{tabular}{|c|c|c|c|}
\hline $\begin{array}{l}\text { Species } \\
\text { Rossignol Wilderness Area }\end{array}$ & $\begin{array}{l}\text { Spore } \\
\text { Prints }\end{array}$ & $\begin{array}{l}\text { Species } \\
\text { Bowater Abitibi Conservation } \\
\text { Easement, Lake Rossignol }\end{array}$ & $\begin{array}{l}\text { Spore } \\
\text { Prints }\end{array}$ \\
\hline Amanita brunnescens G.F.Atk. & No & Austroboletus gracilis (Peck) Wolfe & Yes \\
\hline Amanita ceciliae (Beck\&Broome) Bas & Yes & Boletus cf minato-olivaceus Frost & No \\
\hline Amanita frostiana Peck & Yes & $\begin{array}{l}\text { Cantharellus ignicolor } \\
\text { R.H.Petersen }\end{array}$ & No \\
\hline Boletus subglabripes Peck & Yes & Craterellus fallax A.H.Sm. & No \\
\hline Hygrocybe irrigata (Pers.) Bon & No & Hygrocybe irrigata (Pers.) Bon & No \\
\hline Hygrocybe miniata (Fr.) P. Kumm. & No & Leotia lubrica (Scop.) Pers. & No \\
\hline $\begin{array}{l}\text { Hygrophorus marginatus var. concolor } \\
\text { A.H.Sm. }\end{array}$ & No & Lactarius uvidus (Fr.) Fr. & No \\
\hline $\begin{array}{l}\text { Hygrophorous marginatus var } \\
\text { marginatus } \text { Peck }\end{array}$ & No & Ramaria stricta (Pers.) Quel. & No \\
\hline Lactarius camphoratus (Bull.)Fr. & No & Nolanea strictia (Peck) Largent & Yes \\
\hline Lactarius cinereus Peck & No & Pluteus salicinus (Pers.) P. Kumm. & \\
\hline Lactarius subvellereus Peck & Yes & $\begin{array}{l}\text { Hydnellum caeruleum } \\
\text { (Hornem.) P.Karst. }\end{array}$ & No \\
\hline Pluteus salicinus (Pers.) P.Kumm. & Yes & Russula claroflava Grove & No \\
\hline Russula silvicola Shaffer & Yes & Russula brunneola Burl. & No \\
\hline Russula variata Banning & Yes & Russula fragilis Fr. & No \\
\hline $\begin{array}{l}\text { Strobilomyces strobilaceus (Scop.) } \\
\text { Berk. }\end{array}$ & Yes & Russula heterophylla (Fr.) Fr. & Yes \\
\hline Suillus pictus (Peck) A.H.Sm.\&Thiers & No & Russula variata Banning & Yes \\
\hline Tylopilus felleus (Bull.) P. Karst & No & Suillus americanus (Peck) Snell & No \\
\hline \multirow[t]{3}{*}{ Xanthoconium affine (Peck) Singer } & No & $\begin{array}{l}\text { Tapinella atrotomentosa (Batsch) } \\
\text { Sutara }\end{array}$ & Yes \\
\hline & & $\begin{array}{l}\text { Tylopilus chromapes (Frost) } \\
\text { A.H. Sm. And Thiers }\end{array}$ & No \\
\hline & & Xanthoconium affine (Peck) Singer & Yes \\
\hline
\end{tabular}

\section{Dendrochronology}

Thirty-eight of the 42 cores collected during the Bio-Blitz project illustrated a radial growth pattern and were averaged into a master chronology for the site. The chronology illustrates a similar growth trend to other eastern hemlock found in the region (Robichaud and Laroque 2008, Campbell and Laroque 2007) and spans the time frame from 1661 to 2006 , a 346 year interval.

In general, during the last $\sim 100$ years, radial growth changed from a low at the end of the $19^{\text {th }}$ century, to its best growth during the 1930s and 1940s. From that period until the mid-1970s radial growth was reduced, but it has since taken a marked upturn and is again exhibiting some wide radial growth in the last 30 years, coinciding with recent warming trends in the climate. 


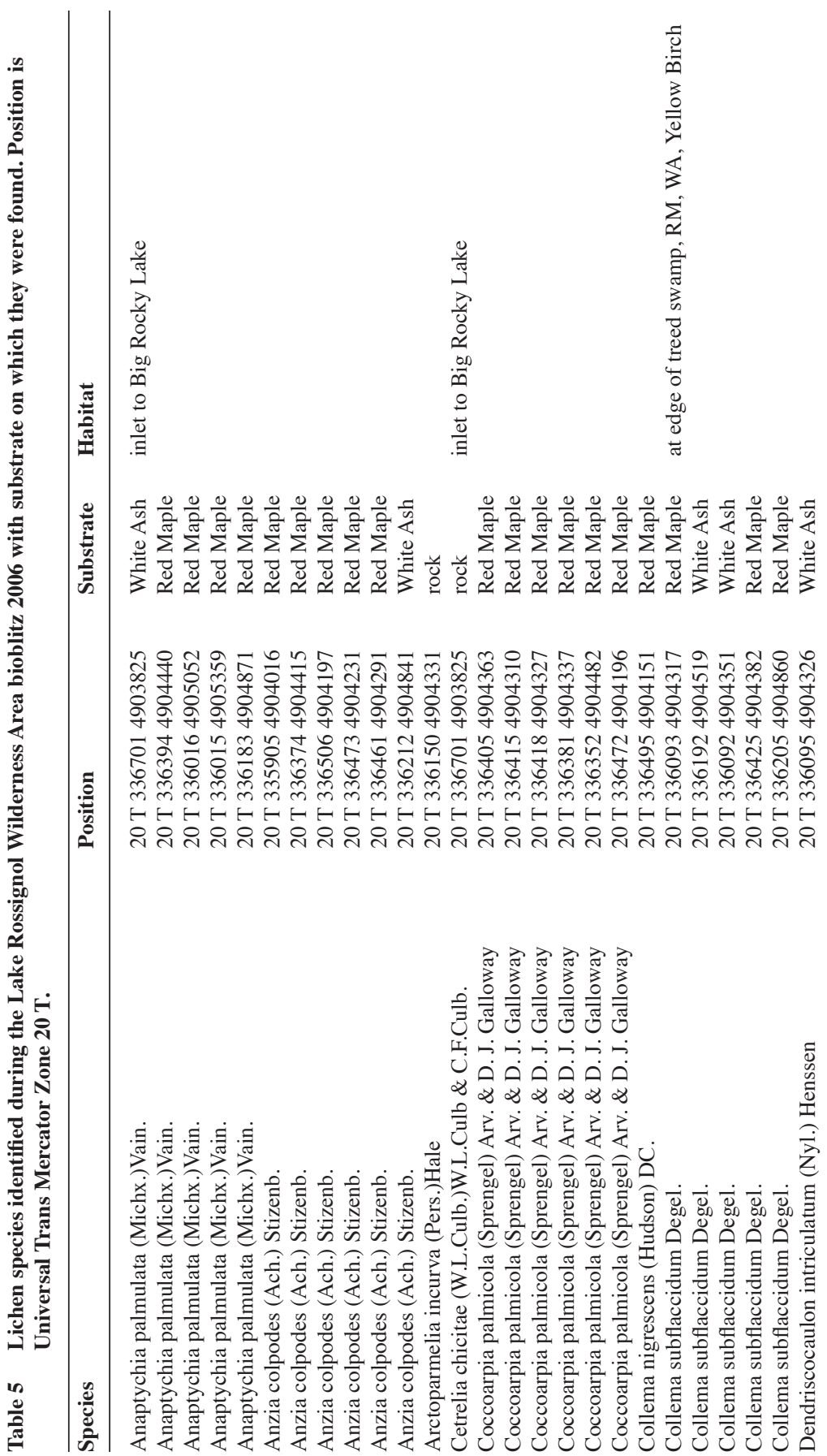




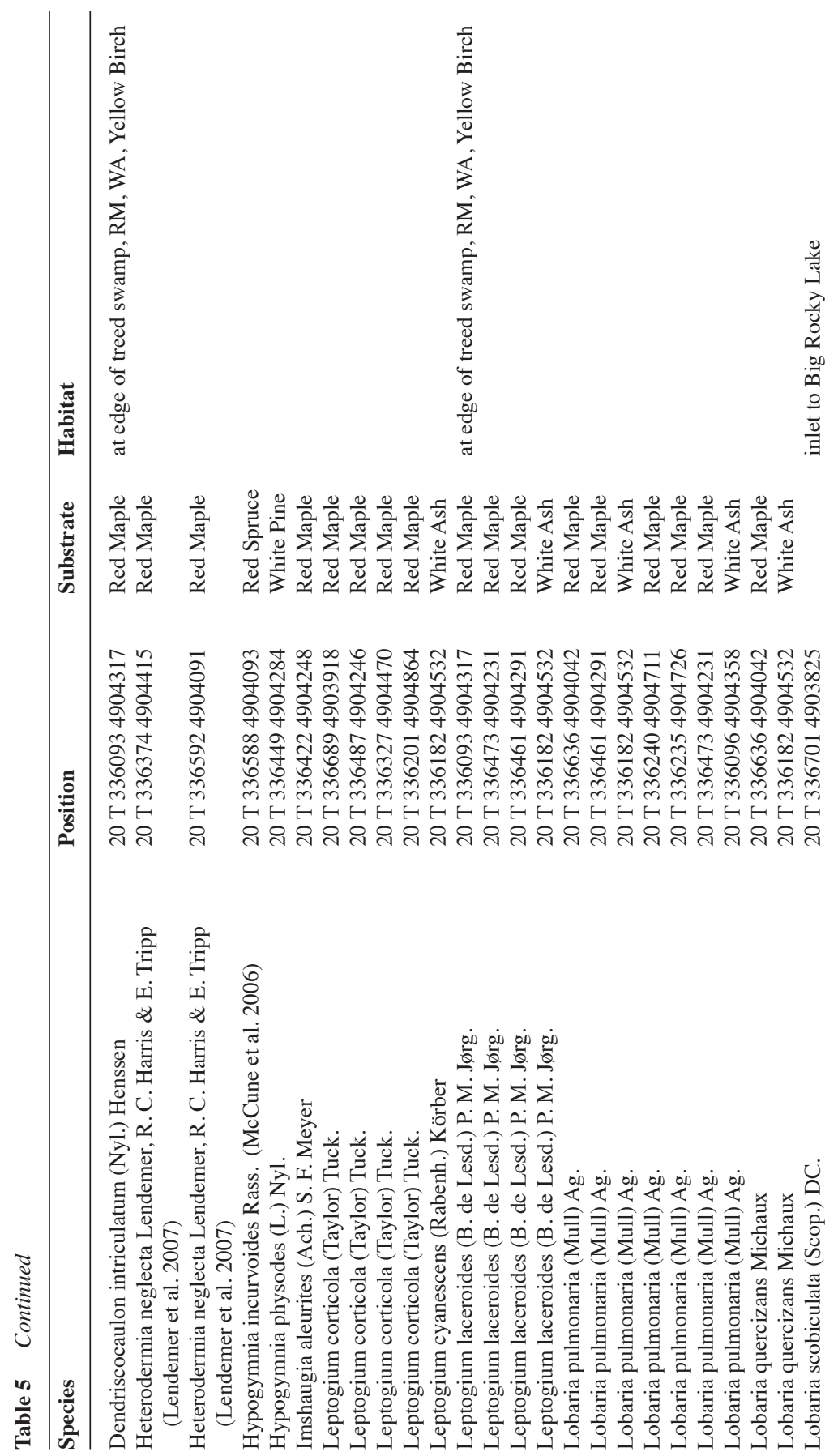




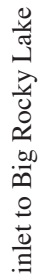

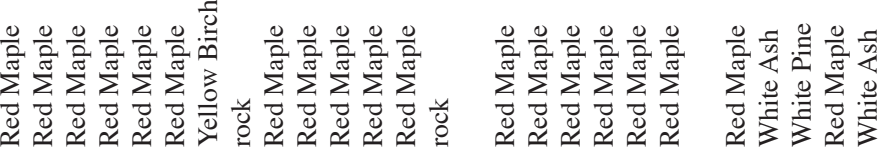





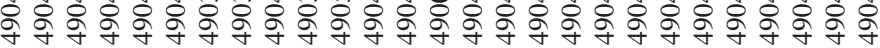

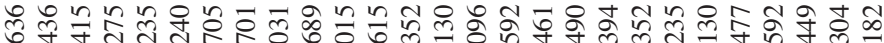
: पै

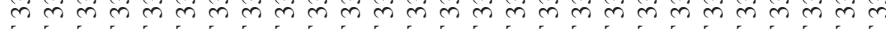

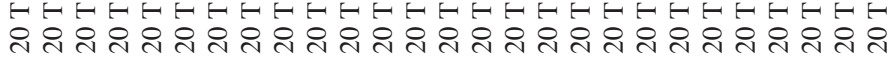

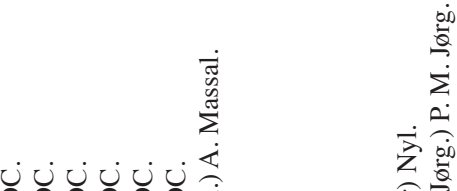

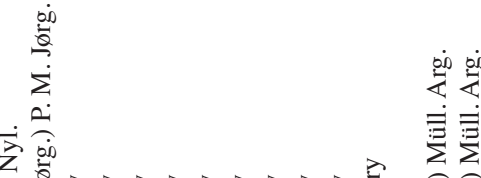

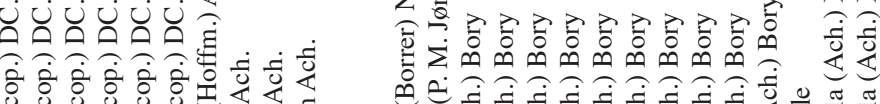

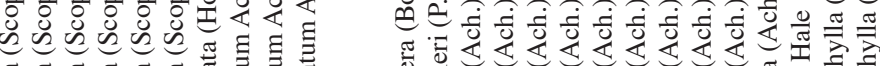

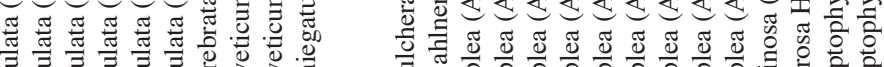

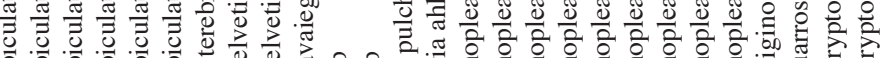

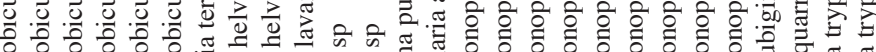
ठ

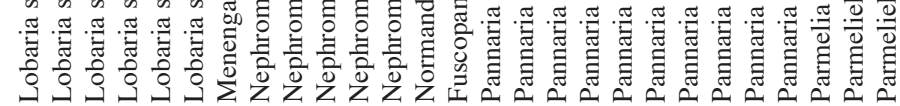




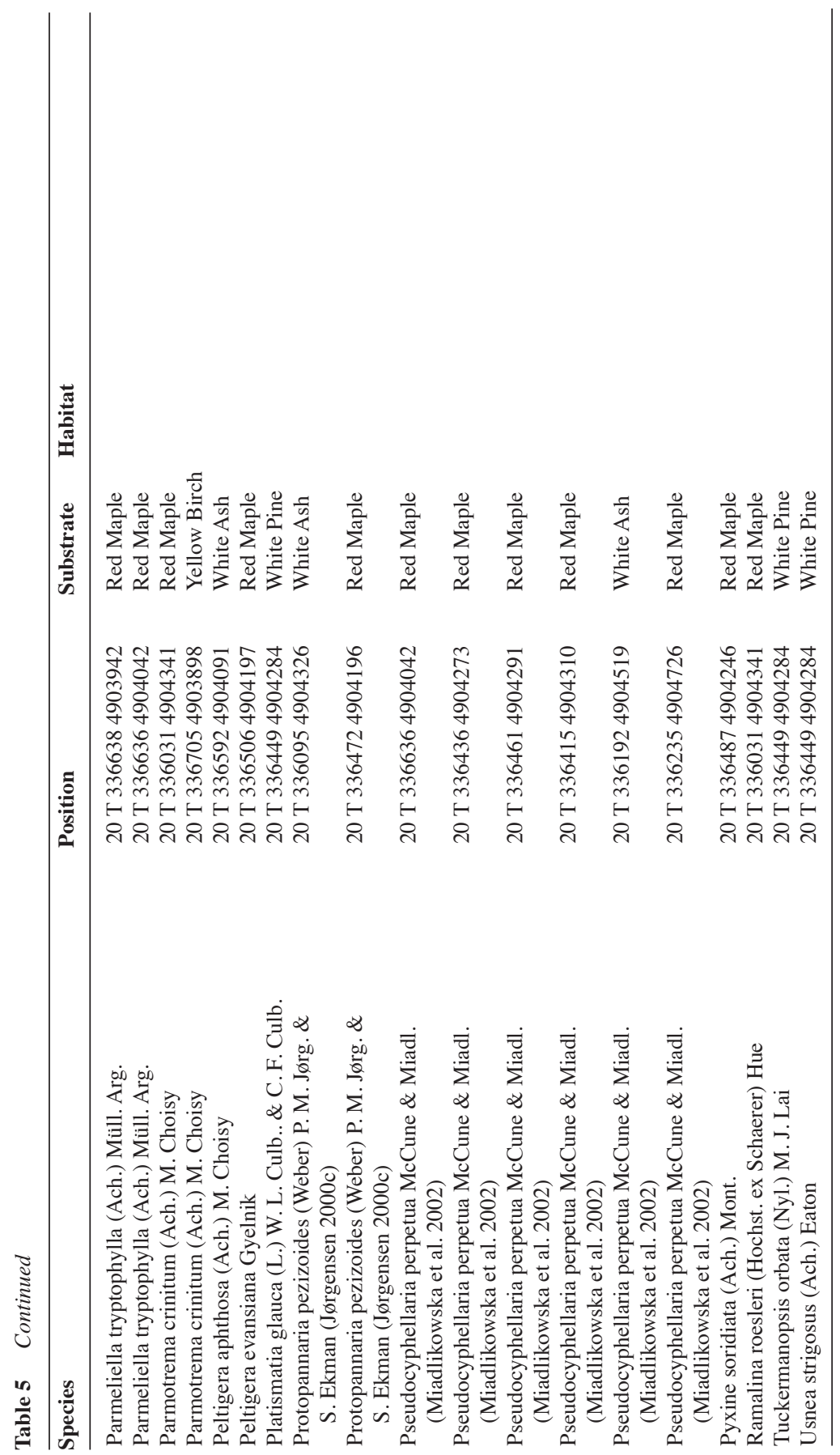


Table 6 Bryophytes identified during the Lake Rossignol Wilderness Area bioblitz, 2006.

Species

Anomodon rostratus (Hedw.) Schimp.

Atrichum alteroristatum

Bazzania trilobata

Bryum argentums

Buxbaumia aphylla Hedw.

Ceptialozia lunulifolia

Dicranum flagellare Hedw.

Dicranum fuscescens Turn.

Dicranum polysetum $\mathrm{Sw}$.

Dicranum scroparium Hedw.

Dicranum viride (Sull. \& Lesq. ex Sull) Lindb.

Diphyscium folusom

Fontinalis novae-angliae

Hylocomium splendens (Hedw.) B.S.G.

Leocobryum glaucoma (Hedw.) Ångstr. ex Fries

Leucodon brachypus var. andrewsianus Crum \& Anderson

Metzgeria conjugate

Mnium hornum Hedw.

Mnium stellare

Neckera pennata Hedw.

Pallavicinia lyellis

Pleurozium schreberi (Brid.) Mitt.

Pohlia nutans (Hedw.) Lindb.

Polytrichum commune

Polytrichum juniperinum

Polytrichum strictum Brid.

Porella platyphylloidea

Ptilium cilare

Ptilium crista-castrensis (Hedw.) De Not.

Rhacomitrium aciculare

Rhizomnium appalachiam

Rhizomnium punctatum

Rhytidiadelphus triquetrus (Hedw.) Warnst.

Sphagnum angustifolium

Sphagnum capifolium

Sphagnum cuspidatum Ehrh. ex Hoffm.

Sphagnum fuscum

Sphagnum girgensohnii Russ.

Sphagnum magellanicum Brid

Sphagnum russowii

Sphagnum squarrosum Crome

Sphagnum torreyanum

Thuidium delicatulum (Hedw.) B.S.G.

Tortella tortuosa (Hedw.) Limpr.

Ulota crispa (Hedw.) Brid.

Ulota coarctata

Ulota hutchinsiae 
Table 7 Species documented in a treed peatland near Little Rocky Lake, Lake Rossignol Wilderness Area, Nova Scotia. Note: Coastal Plain species are noted with an asterisk (*).

\begin{tabular}{|c|c|}
\hline Taxon & Species Observed in Bog \\
\hline Odonates & $\begin{array}{l}\text { Variable Darner (Argia fumipennis Burmeister) } \\
\text { Calico Pennant (Celithemis elisa } \text { Hagen) } \\
\text { Petite Emerald (Dorocordulia lepida Hagen) } \\
\text { Hagen's Bluet (Enallagma hageni Walsh) } \\
\text { Orange Bluet (Enallagma signatum Hagen) } \\
\text { Eastern Forktail (Ischnura verticalis Say) } \\
\text { Sphagnum Sprite (Nehalennia gracilis Morse) } \\
\text { Cherry-faced / Ruby Meadowhawk } \\
\text { (Sympetrum internum/ rubicundulum Montg.) } \\
\text { Band-winged Meadowhawk } \\
\text { (Sympetrum semicinctum Say) }\end{array}$ \\
\hline Tabanid Flies & $\begin{array}{l}\text { Chrysops delicatulus Osten Sacken } \\
\text { Chrysops vittatus Weideman } \\
\text { Hybomitra microcephala Osten Sacken } \\
\text { Hybomitra pechumani Teskey and Thomas }\end{array}$ \\
\hline Sphagnum Mosses & $\begin{array}{l}\text { Sphagnum angermanicum Melin } \\
\text { Sphagnum angustifolium (Russ) J. Jens } \\
\text { Sphagnum austinii } \\
\text { Sphagnum capillifolium } \\
\text { Sphagnum cuspidatum } \\
\text { Sphagnum fallax Klinggr. } \\
\text { Sphagnum flavicomans (Card.) Warnst. } \\
\text { Sphagnum flexuosum Dozy \& Molk. } \\
\text { Sphagnum fuscum } \\
\text { Sphagnum girgensohnii } \\
\text { Sphagnum magellanicum } \\
\text { Sphagnum majus (Russ) J. Jens } \\
\text { Sphagnum quinquefarium (Lindb. ex Braithw.) Warnst. } \\
\text { Sphagnum warnstorfii Russ. }\end{array}$ \\
\hline $\begin{array}{l}\text { Woody Vegetation } \\
\text { (in Peatland) }\end{array}$ & $\begin{array}{l}\text { Larch (Larix laricina (DuRoi) K.Koch) } \\
\text { Black Spruce (Picea mariana (Mill.) BSP.) } \\
\text { White pine (Pinus strobus) } \\
\text { Red Maple (Acer rubrum) } \\
\text { Red Chokeberry (Aronia arbutifolia (L.) Ell.)* } \\
\text { Black Chokeberry (Aronia melanocarpa (Michx.) Ell.) } \\
\text { Huckleberry (Gaylussacia baccata) } \\
\text { False Holly (Nemopanthus mucronata) } \\
\text { Lambkill (Kalmia angustifolia) } \\
\text { Bog Laurel (Kalmia polifolia) } \\
\text { Blueberry (Vaccinium angustifolium) } \\
\text { Wild Raison (Viburnum cassinoides) } \\
\text { Labrador Tea (Ledum groenlandicum) } \\
\text { Sweet gale (Myrica gale) } \\
\text { Rhodora (Rhododendron canadense) } \\
\text { Common Juniper (Juniperus communis L.) } \\
\text { Leatherleaf (Chamaedaphne calyculata) } \\
\text { Large Cranberry (Vaccinium macrocarpon) } \\
\text { Small Cranberry (Vaccinium oxycoccos L.) } \\
\text { Serviceberry (Amelanchier sp.) }\end{array}$ \\
\hline
\end{tabular}


Table 7 Continued

\begin{tabular}{ll}
\hline Taxon & Species Observed in Bog \\
\hline & Tea berry (Gaultheria procumbens) \\
& Black Crowberry (Empetrum nigrum L.) \\
Woody Vegetation & Speckled Alder (Alnus incana (L.) Moench) \\
(from Lagg) & Inkberry* (Ilex glabra) \\
& Bayberry* (Myrica pensylvanica) \\
& Steeplebush (Spirea tomentosa) \\
& Poison Ivy* (Toxicodendron radicans) \\
& Orchid hybrid \\
Other Species & (Platanthera blephariglottis X P. dilatata (Wild.) Lindl.) \\
& Rose Pogonia (Pogonia ophioglossoides (L.) Ker-Gawler) \\
& White-fringed Orchid* \\
& (Platanthera blephariglottis (Wild.) Lindl.) \\
& Pink Lady Slipper (Cypripedium acaule) \\
& Round-leafed Sundew (Drosera rotundifolia L.) \\
& Pitcher Plant (Sarracenia purpurea L.) \\
& Bog Goldenrod (Solidago uliginosa Nutt.)* \\
& Marsh St Johns-wort* (Triadenum virginicum (L.) Raf.) \\
\hline
\end{tabular}

The data collected at the Bio-Blitz site contributes to understanding the protected area. Trees at the site have been growing in place for at least the last 350 years.

\section{Peatland}

The peatland had vegetation suggestive of a fen such as sedges and grasses. However, it also contained several plant species that are more typical of poor-nutrient ombrotrophic bogs, including black crowberry (Empetrum nigrum) and lambkill (Kalmia angustifolia) (Crum 1992).

Plant species richness of the Lake Rossignol Wilderness Area was high compared to other peatlands in the region (D. Hurlburt, unpublished data) (Table 7). Fourteen Sphagnum species (44\% of Nova Scotia total) and 22 woody vegetation species (14\% of Nova Scotia total) were observed. However, tabanid and odonate diversities were lower than expected with only nine species of odonates and four species of tabanid flies recorded. It is suspected that the overcast, wet and cool weather on the sampling day was not amenable to insect emergence and flight.

Seven of thirty-five species of vascular plants found are of a Coastal Plain Distribution. All of these species are both locally and globally secure (Zinck 1998). 


\section{CONCLUSION}

The scientific usefulness of the bioblitz was clearly demonstrated. A total of 294 species were identified during the survey, 285 of which are new records for the Wilderness Area. The identification of sites of five species-at-risk will enable protected areas managers to tailor management plans to ensure their conservation. These findings also highlight the importance of protected areas to species-at-risk conservation. The data from this study can also provide a base from which to build a more complete inventory of the Wilderness Area. Another area where bioblitzes can be useful is the identification of invasive species which require monitoring or control (Meshaka et al. 2008, Karns et al. 2006). Although this study did not result in the identification of invasive species in the Wilderness Area, more intensive surveys may be needed. This bioblitz brought together scientists from a variety of disciplines that might not normally interact and may result in further collaborations among disciplines and agencies.

Acknowledgements We would like to thank Protected Areas and Wetlands Branch of Nova Scotia Environment for organizing the event. We would also like to thank Mersey Tobeatic Research Institute, particularly Amanda Lavers, for hosting an evening and promoting the event and David Garbary for providing helpful review of the manuscript.

\section{LITERATURE CITED}

Alexander, D.R., Kerekes, J.J., Sabean, B.C. (1986) Description of selected lake characteristics and occurrence of fish species in 781 Nova Scotialakes.Proceedings of the Nova Scotia Institute of Science 36: 63-106. Anderson, F (2007) An assessment of the status of cyanolichens in Nova Scotia. Evansia 24: 23-24.

Brodo, I.M., Sharnoff, S.D., Sharnoff, S. (2001) Lichens of North America. Yale University Press, New Haven.

Cameron, R.P. (2004) Resource Guide and Ecological Atlas: for Conducting Research in Nova Scotia's Wilderness Areas and Nature Reserves. Protected Areas Branch, Nova Scotia Department of Environment and Labour Technical Report 0401.

Campbell, L.J., Laroque, C.P. (2007) Decay progression in two oldgrowth forests in Atlantic Canada. Forest Ecology and Management 238: 293-301 
Crum, H.A. (1992) A Focus on Peatlands and Peat Mosses. The University of Michigan Press, Ann Arbor.

Davis, D.S., Browne,S. (1996) Natural History of Nova Scotia. Nova Scotia Museum and Nimbus Publishing, Halifax.

Cook, E.R. (1999) TurboARSTAN program and reference manual, V 2.0.7 February, 1999. Tree-ring Laboratory, Lamont-Doherty Earth Observatory, Palisades, New York.

Environment Canada (2004) Canadain Acid Deposition Science Assessment: Summary of Key Results. Environment Canada, Ottawa.

Gilhen, J. (1984) Amphibians and Reptiles of Nova Scotia. Nova Scotia Museum, Halifax.

Graham, S.P., Steen, D.A., Nelson, K.T., Durso, A.M., Maerz, J.C. (2010) An Overlooked Hotspot? Rapid Biodiversity Assessment Reveals a Region of Exceptional Herpetofaunal Richness in the Southeastern United States. Southeastern Naturalist 9: 19-34.

Harper, M.A., Patterson, J.E., Harper, J.F. (2009) New diatom taxa from the world's first marine Bioblitz in New Zealand: Skeletomastus a new genus, Skeletomastus coelatus nov.comb. and Pleorosigma inscriptura a new species. Acta Bot. Croat. 69: 339-349.

Holmes, R.L., Adams, R.K., Fritts, H.C. (1986) Tree-ring chronologies of Western North America: California, Eastern Oregon and Northern Great Basin, with procedures used in the chronology development work, including user manuals for computer programs COFECHA and ARSTAN. Chronology Series VI. Laboratory of Tree-Ring Research, University of Arizona, Tucson.

Ireland, R.R. (1982) Moss Flora of the Maritime Provinces. National Museums of Canada, Ottawa.

Karns, D.R., Ruch, D.G., Brodman, R.D.„Jackson, M.T., Rothrock, P.E., Scott, P.E., Scott, T.P., Whitaker, J.O. Jr. (2006) Results of a short-term BioBlitz of the aquatic and terrestrial habitats of Otter Creek, Vigo County, Indiana. Proceedings of the Indiana Academy of Science 115: 82-88.

Lendemer, J.C., Hodkinson, B.P. (2009) Stretching the boundaries: a range extension for Buellia wheeleri R.C. Harris. Evansia 26: 172-176.

Lewington, R.J., West, C.J. (2008) Otari Bioblitz: detailing vascular plants, mosses and liverworts. Wellington Botanical Society Bulltein 51: 5-23.

Lynds, J.A., LeDuc, J.M. (1995) Planning for the protection of biodiversity at the landscape level in Nova Scotia. In: Herman TB, BondrupNielsen S, Willison JHM, Munro NWP (eds) Proceedings of the Second International Conference on Science and the Management of Protected Areas. Dalhousie University, Halifax. Pp. 548-558.

McMaster, N., Herman, T.B. (2000) Occurrence, habitat selection and movement patterns in juvenile Blanding's turtles (Emydoidea blandingii) in Kejimkujik National Park, Nova Scotia. Chelonian Conservation and Biology 3: 602-610. 
Meshaka, W.E., Smith, H.T., Gibbons, J.W., Jackson, T., Mandica, M., Boler, K.A. (2009) An exotic herptofaunal bioblitz survey at a State Park in southern Florida. Journal of Kansas Herptology 26: 14-16.

Ouimet, R., Arp, P.A., Watmough, S.A., Aheme, J., DeMerchant, I. 2006. Determination and mapping of critical loads of acidity and exceedances for upland forest soils in Eastern Canada. Water, Air and Soil Pollution 172: 57-66.

Peterson, R.H., Martin-Robichaud, D.J. (1989) Community analysis of fish populations in headwater lakes of New Brunswick and Nova Scotia. Proceedings of the Nova Scotia Institute of Science 38: 55-72.

Robichaud, A., Laroque, C.P. (2008) Dendroarchaeology in southwestern Nova Scotia and the construction of a regional red spruce chronology. Tree-Ring Research 64: 17-25.

Shorthouse, J. (2010) Update on the Biological Survey of Canada/Commission Biologique du Canada activities. Newsletter of the Biological Survey of Canada 29: 3-4.

Telfer, E.S. (2004) Continuing environmental change - an example from Nova Scotia. Canadian Field Naturalist 118: 39-4.

Underwood, J.K., Ogden J.G., Kerekes, J.J., Vaughn, H.H. (1987) Acidification of Nova Scotia Lakes. Water, Air and Soil Pollution 32: 77-88.

Zinck, M. (1998) Roland's Flora of Nova Scotia. Nimbus Publishing and Nova Scotia Museum, Halifax. 
